\title{
RENAL FUNCTION AND ELECTROLYTE METABOLISM IN ACUTE GLOMERULONEPHRITIS '
}

\author{
By D. P. EARLE, S. J. FARBER, J. D. ALEXANDER, ANd E. D. PELLEGRINO \\ (From The Department of Medicine, New York University College of Medicine, \\ New York, N. Y.)
}

(Submitted for publication November 24, 1950; accepted, February 16, 1951)

Glomerular changes are perhaps the most outstanding anatomical lesions of acute glomerulonephritis. The glomerular tuft usually exhibits increased cellularity with deposits of fibrin or inflammatory exudate in the capsular space. The capsule and basement membranes may become thickened but the arterioles and renal tubules appear relatively normal in the early phases of the disease. Several papers describe a characteristic functional pattern for acute glomerulonephritis which reflects the dominant glomerular lesion $(1-4)$.

The purpose of the present paper is to describe the relation of changes in renal functions to the development of the clinical manifestations of acute glomerulonephritis and of the exacerbation in chronic glomerulonephritis, especially in regard to water and electrolyte metabolism. The renal functions measured include glomerular filtration rate (GFR), effective renal plasma flow (ERPF) and maximum capacity of the renal tubules to excrete p-aminohippurate $\left(\mathrm{Tm}_{\mathbf{P A B}}\right)$ or to reabsorb glucose $\left(\mathrm{Tm}_{\mathrm{G}}\right)$.

\section{CASE MATERIAL}

Facts relative to the diagnosis and onset of the disease for each patient are summarized in Table I. Elevated antistreptolysin titers (5) indicated a recent group $A$ hemolytic streptococcal infection in 10 instances. Evidence of prior renal disease was absent in the eight patients classified as acute glomerulonephritis. Several may have had unrecognized chronic glomerulonephritis and their acute attack may have been an exacerbation rather than the initial attack. However, initial attacks seem likely in the five episodes that "healed" 2 and in the two

\footnotetext{
1 Supported by a grant from the Life Insurance Medical Research Fund.

2 Only relatively short follow-up periods were possible in the majority of the patients comprising this study. Thus, certain differentiation between complete healing and the development of chronicity following acute glomerulonephritis was difficult and sometimes impossible (6). However, patients 9, 10 and 11 were known to have chronic glomerulonephritis for one or more years
}

patients whose urine and blood pressure were normal 16 and 35 days before the onset of signs and symptoms of renal disease. Four instances of exacerbation in chronic glomerulonephritis were observed, one of which occurred in patient 8 , whose initial attack of acute glomerulonephritis was also studied. The criterion accepted for the diagnosis of exacerbation in chronic glomerulonephritis was "an abrupt and marked increase in the degree of hematuria" (8). Foreshortening of the latent period between infection and onset of symptoms characteristic of the exacerbation $(8,9)$ was noted in two of these patients.

The initial and final observations on the urine, blood pressure and edema for each patient are shown in Table II, along with the duration of the abnormalities. The final probable outcomes are indicated in the last column. ${ }^{2}$

The sudden development of nephrotic edema was not accepted as evidence either for the initial acute attack of glomerulonephritis or for an exacerbation in glomerulonephritis. At the time of observation, none of the patients had evidence of the nephrotic phase. Their serum albumin averaged $3.2 \mathrm{gm} . / 100 \mathrm{ml}$. with a range of 2.5 to 4.5 , while their serum cholesterol averaged 219 $\mathrm{mg} . / 100 \mathrm{ml}$. with a range of 179 to 294 .

Signs and symptoms of congestive heart failure were present during the acute renal episode in only two patients (patients 9 and 11). These two patients suffered

prior to observation. Patient 8 was seen during his first attack and subsequently during an exacerbation. $\mathrm{Pa}$ tients 6 and 7 were seen periodically during one and one half and one years respectively after their initial attacks. During this time proteinuria persisted, a fact which supports the belief that the disease had probably become chronic. Patient 5 was followed for slightly more than one year after his acute glomerulonephritis. The last six urinalyses were normal, quite suggestive of healing. Patient 1 had three normal urines before loss for observation and likewise probably healed. Patients 2, 3 and 4 had three, three and two protein-free urines. However, minimal to moderate microscopic hematuria was still present at the last examination. Since microscopic hematuria may be one of the last abnormal signs to disappear during the healing of acute glomerulonephritis (7), these patients were classified as "probably healing," and included in the "healed" group in the subsequent discussions. Although a follow-up period of a year or more is necessary to differentiate with certainty between healing and chronicity, the presumptive outcomes in this group of patients are designated. 
TABLE I

Data concerned with the onset and diagnosis of acute episodes of glomerulonephritis

\begin{tabular}{|c|c|c|c|c|c|c|c|}
\hline $\begin{array}{l}\text { PATIENT } \\
\text { mUMBeE }\end{array}$ & $\operatorname{sex}$ & $\frac{A G E}{(y e a r a)}$ & PAECEDIME InRECTIS & 1100 & $\frac{{ }_{\text {AnTISTREPTOLYSIN }}^{\text {TITER }}}{\text { (Units) }}$ & $\begin{array}{l}\text { LATENT } \\
\text { PERRIOD } \\
\text { (days) }\end{array}$ & ONSET MEPHRITIS \\
\hline 1 & $\mathbf{M}$ & 53 & Disecherge righe wo & noetril & 100 & $?$ & $\begin{array}{l}\text { Acute } \\
\text { Edeme eyes, feet } \\
\text { Scanty urine } \\
\text { Microscopic hematurie } \\
\text { Hypertension }\end{array}$ \\
\hline 2 & $m$ & so & $\begin{array}{l}\text { Tonsillitis, Fever } \\
\text { Rx: Sulfadiazine }\end{array}$ & & 2000 & 20 & $\begin{array}{l}\text { Acute } \\
\text { Edeme eyes, feet } \\
\text { Microscopic hematuria } \\
\text { Hypertension }\end{array}$ \\
\hline 3 & M & 56 & $\begin{array}{l}\text { R.U.L. Paeumonia } \\
\text { Rx: Penicillía } \\
\text { (pneusococel not } \\
\text { dewongtraced) }\end{array}$ & & 200 & 19 & $\begin{array}{l}\text { Acute } \\
\text { (Urine, BP normal } 16 \text { days } \\
\text { before onset) } \\
\text { Edema eyes, feet } \\
\text { Microscopic hematuria } \\
\text { Hypertension }\end{array}$ \\
\hline 4 & $m$ & 35 & Severe sore throat & at & $>2000$ & & $\begin{array}{l}\text { Acute } \\
\text { Edema legs } \\
\text { Microscopic hematuria } \\
\text { Hypercension }\end{array}$ \\
\hline 5 & M & 43 & $\begin{array}{l}\text { Chronic cough } \\
\text { "Frequent coldse" }\end{array}$ & & 300 & $?$ & $\begin{array}{l}\text { Acute } \\
\text { Scanty dark urine } \\
\text { F.dema legs } \\
\text { Hypertiension }\end{array}$ \\
\hline 6 & $M$ & 47 & None noted & & 200 & $?$ & $\begin{array}{l}\text { Acute } \\
\text { Abdominal cramps } \\
\text { Smoky urine } \\
\text { Edema face. legs } \\
\text { Hypertension }\end{array}$ \\
\hline 7 & $\mathbf{F}$ & 46 & $\begin{array}{l}\text { Postop (cervix) I } \\
\text { Rx: Peaicillin }\end{array}$ & Infection & 900 & $\begin{array}{c}35 \\
\text { (postop) }\end{array}$ & $\begin{array}{l}\text { Acute } \\
\text { ('Irine, BP normal pre-op.) } \\
\text { Edema eyes, feet } \\
\text { Microscopic hematuria } \\
\text { Hypertension }\end{array}$ \\
\hline 8. 11 & $M$ & 46 & Fever, cough & $\cdot$ & 400 & 8 & $\begin{array}{l}\text { Acute } \\
\text { Bloody urine } \\
\text { Edema eyes. feet } \\
\text { Hypertension }\end{array}$ \\
\hline 8. 12 & & & Moleise & . & 500 & 0 & $\begin{array}{l}\text { Exacerbation } \\
\text { Rloody urine } \\
\text { Edema eyes. feet } \\
\text { Hypertension }\end{array}$ \\
\hline 9 & $\mathbf{F}$ & 56 & Sore throet & & $\cdots$ & 1 & $\begin{array}{l}\text { Exacerbation } \\
\text { (disease known 1 year) } \\
\text { Edema feet } \\
\text { Flank pain } \\
\text { Red urine } \\
\text { Hypertension } \\
\text { Ovspnes }\end{array}$ \\
\hline 10 & $M$ & 63 & Cold, fover & 4 & 100 & 3 & $\begin{array}{l}\text { Fxacerbation } \\
\text { (Initial attack } 22 \text { years ago } \\
\text { (Exacerbation } 12 \text { years ago) } \\
\text { f.dema legs } \\
\text { Pain low hack } \\
\text { Red urine }\end{array}$ \\
\hline 11 & $M$ & 32 & None noted & $\therefore \ldots$ & 400 & $?$ & $\begin{array}{l}\text { Exacerbation } \\
\text { (disense known } 15 \text { years) } \\
\text { Dyspnes } \\
\text { Orthopnen } \\
\text { Edemo } \\
\text { Oliguria }\end{array}$ \\
\hline
\end{tabular}


TABLE II

Initial and final observations on urine, edema and blood pressure

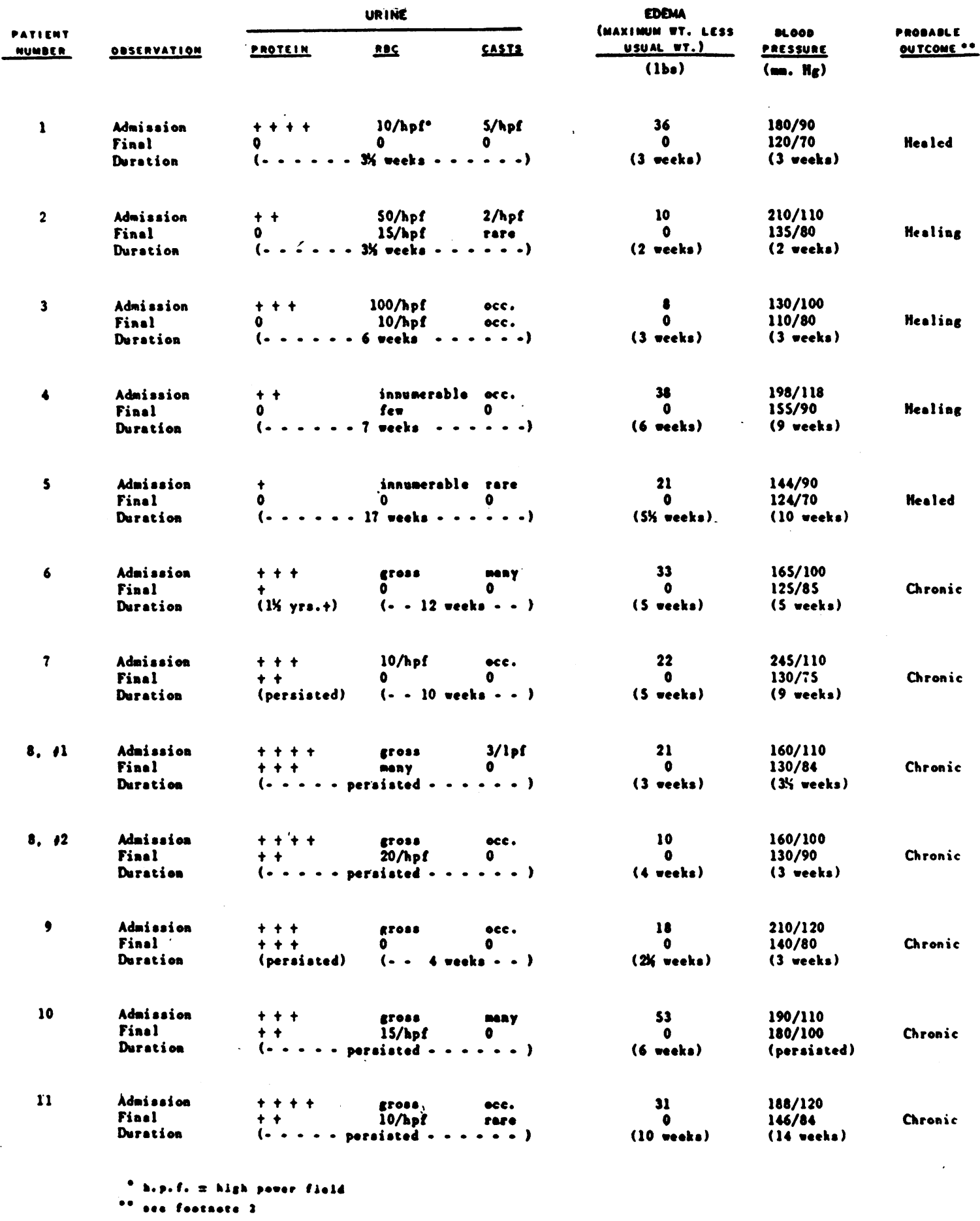


from dyspnea and orthopnea, had elevated venous pressures and prolonged circulation time. Their hearts were enlarged.

\section{METHODS}

All data presented represent an average of three or more consecutive 15 to 30 minute periods. All observations were performed in the morning. Fluids and food were withheld after the preceding evening meal. Following three periods during which inulin and PAH clearances and electrolyte excretion were observed, $\mathrm{Tm}$ glucose or $\operatorname{Tm}_{\mathrm{PAB}}$ were measured for three consecutive periods. Priming and sustaining infusions containing inulin and PAH were made up in distilled water. The sustaining infusion was delivered by means of a pump at the rate of $1 \mathrm{ml} . /$ minute during the first three periods, and at a rate between 2 and $5 \mathrm{ml} . /$ minute during $\mathrm{Tm}$ measurements. An arterial blood sample was obtained at the midpoint of each urine collection. Plasma, separated from the erythrocytes within 15 minutes of withdrawal of the blood sample, was used for the potassium, chloride, inorganic phosphate, inulin, $\mathrm{PAH}$ and glucose determinations. Dried heparin and a small amount of sodium fluoride were used to prevent clotting and glycolysis in the case of glucose and inorganic phosphate, while dried heparin alone was used to prevent clotting in the sample subjected to the other analyses. Serum was used for the sodium determinations.

Inulin was measured by Harrison's (10) modification of the method of Alving, Rubin and Miller (11), PAH by the Bratton-Marshall reaction (12), and glucose by a modification (13) of the Folin method. Sodium in the serum and urine and potassium in the plasma and urine were measured on an internal standard flame photometer. Chlorides were measured by a modification of the Volhard-Harvey method (14), inorganic phosphate by the method of Fiske and SubbaRow (15), and ammonia and urea by Summerson's modification (16) of the Van Slyke and Cullen procedure. Urine $\mathrm{pH}$ was determined with the glass electrode.

\section{RESULTS}

\section{(A) Renal functions}

Renal functions, weight, blood pressure and urinary abnormalities are recorded in Table III in relation to time of onset and of diuresis. The renal function values are not corrected to a standard surface area because of the complications this would introduce in the subsequent considerations of electrolyte excretions. Glomerular filtration rate was definitely reduced at the first observation in all but one instance (patient 2 ). The renal plasma flow ${ }^{8}$ was less affected and was in the normal

3 The renal plasma flow values in this study are not corrected for any possible incomplete extraction of PAH by the renal tubules. The true renal plasma flow in any range at the first observation in four of the eight initial attacks of acute glomerulonephritis. The pattern of renal dysfunction in both initial attacks and in exacerbations was characteristic of that previously described for acute glomerulonephritis. The filtration fraction (GFR/RPF) was reduced (less than the mean normal value minus two standard deviations) at some time in eight of the 12 episodes. $\mathrm{Tm}_{\mathrm{G}}$ was reduced in eight of the nine instances in which it was measured, and $T_{\mathrm{PAB}}$ in seven of nine instances. The ratios of filtration rate to $\mathrm{Tm}_{G}$ and $T \mathrm{~m}_{\mathbf{P A B}}$ were usually reduced, indicating a greater impairment of glomerular activity than of tubular function. Several exceptions, however, were noted. In the instance of the four exacerbations the renal functions were undoubtedly abnormal prior to the observations because of the chronic renal disease but exhibited the same general pattern as the initial attacks.

Following the acute episode all functions returned toward normal in patients suffering either their first attack or an exacerbation. $\mathrm{Tm}_{\mathrm{G}}$ and $T_{\text {PAB }}$ were in the normal range at the time of the last observation in four of the five patients who healed or were probably healing (see footnote 2) while the filtration rate had returned to low normal values in three. These findings are similar to those reported in an earlier paper (1) which included observations on five patients suffering their initial attack of glomerulonephritis and two undergoing exacerbations. Serial observations on eight patients in the present study and five patients in the earlier study (1) are available in whom the outcome of the initial attack of acute glomerulonephritis was known (see footnote 2). The first estimation of renal function was obtained within two weeks or less of the onset of the disease in only five of the 13 patients. The serial filtration rates are presented in Figure 1. In general, a smaller reduction in filtration rate and a more rapid return to normal occurred among the six patients whose nephritis healed or probably healed than among the seven whose disease became chronic. Of the nine patients studied within four weeks of the onset of nephritis, the three whose disease failed to heal had initial filtration rates below $55 \mathrm{ml}$./ minute, while those who healed had rates of 44 , instance where there is incomplete extraction of PAH is, therefore, higher than the recorded value. 
ถึ)

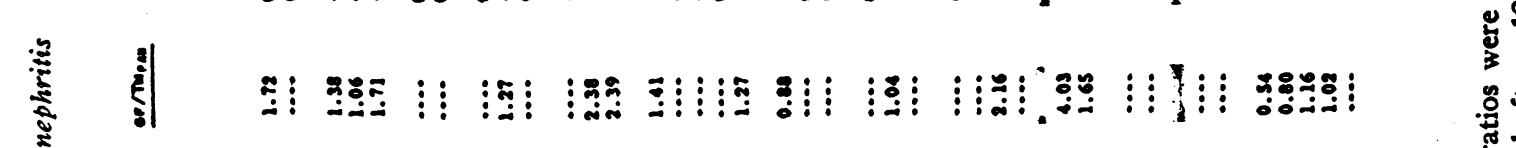

年

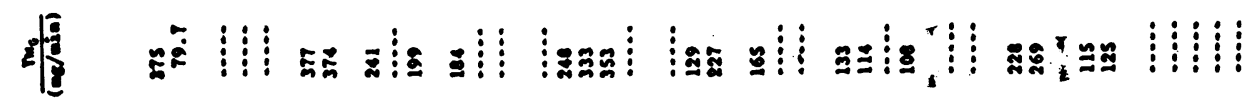

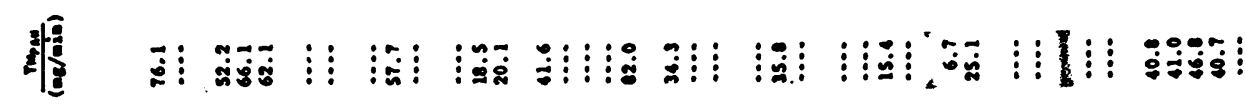

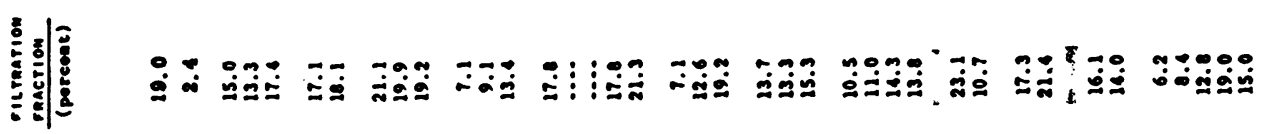

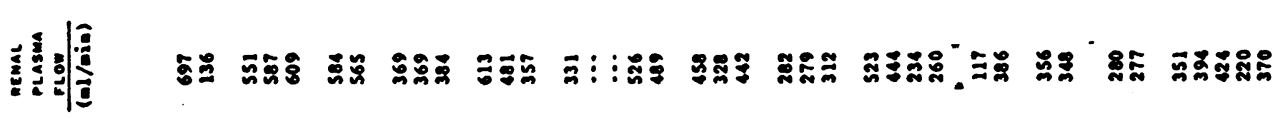

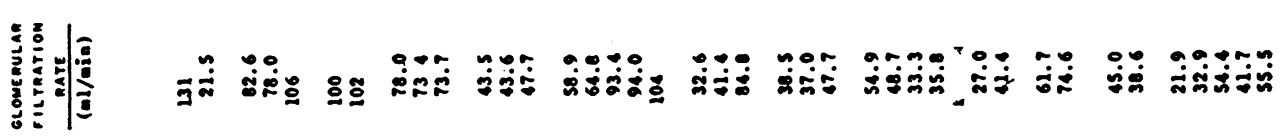

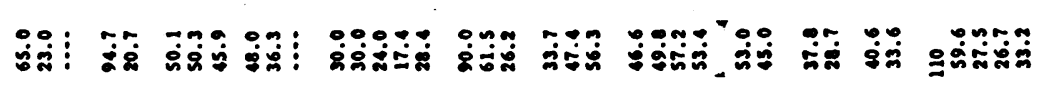

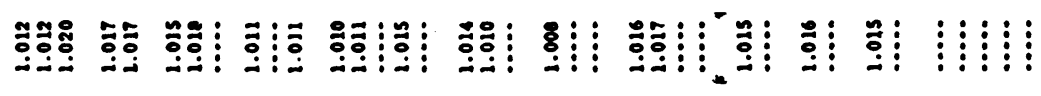

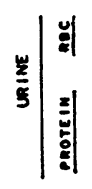

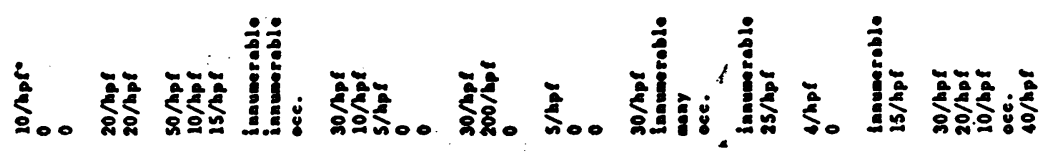

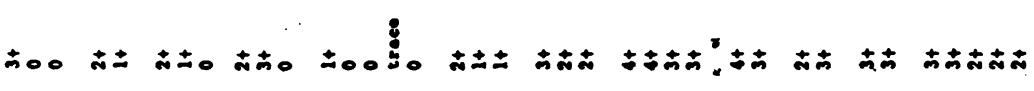

i

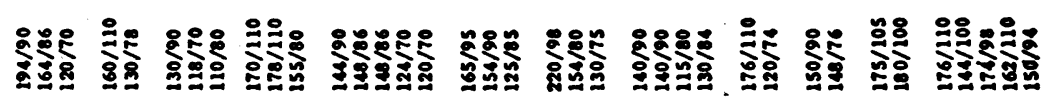

:

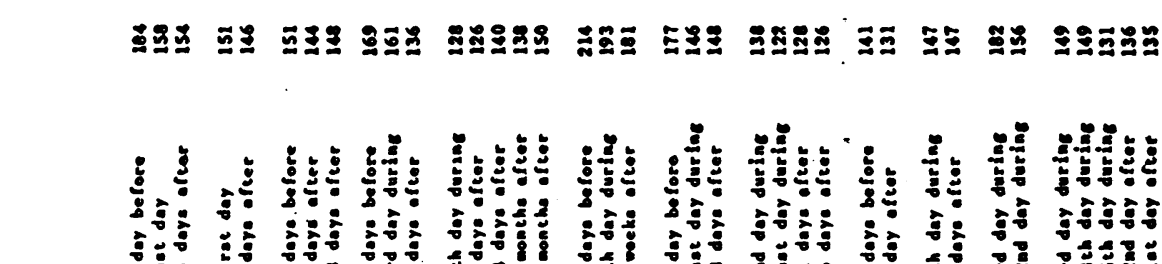

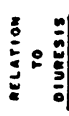

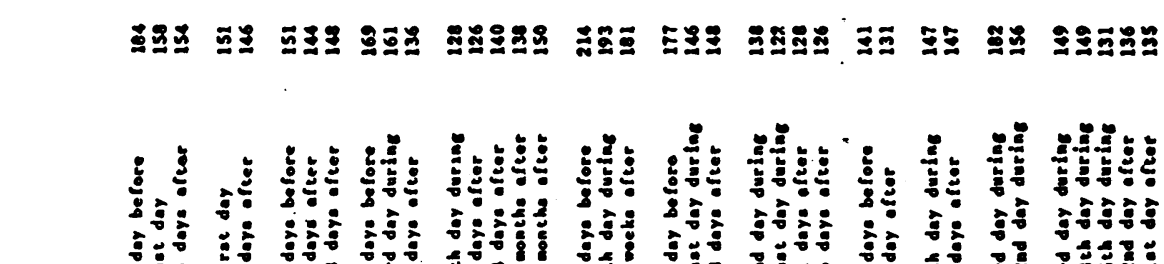

空

\&

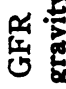

营苞

उั

도.

马्.

妾

苾

동

究

晃

总

है

8 in

$\Xi$

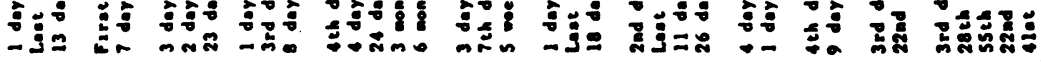




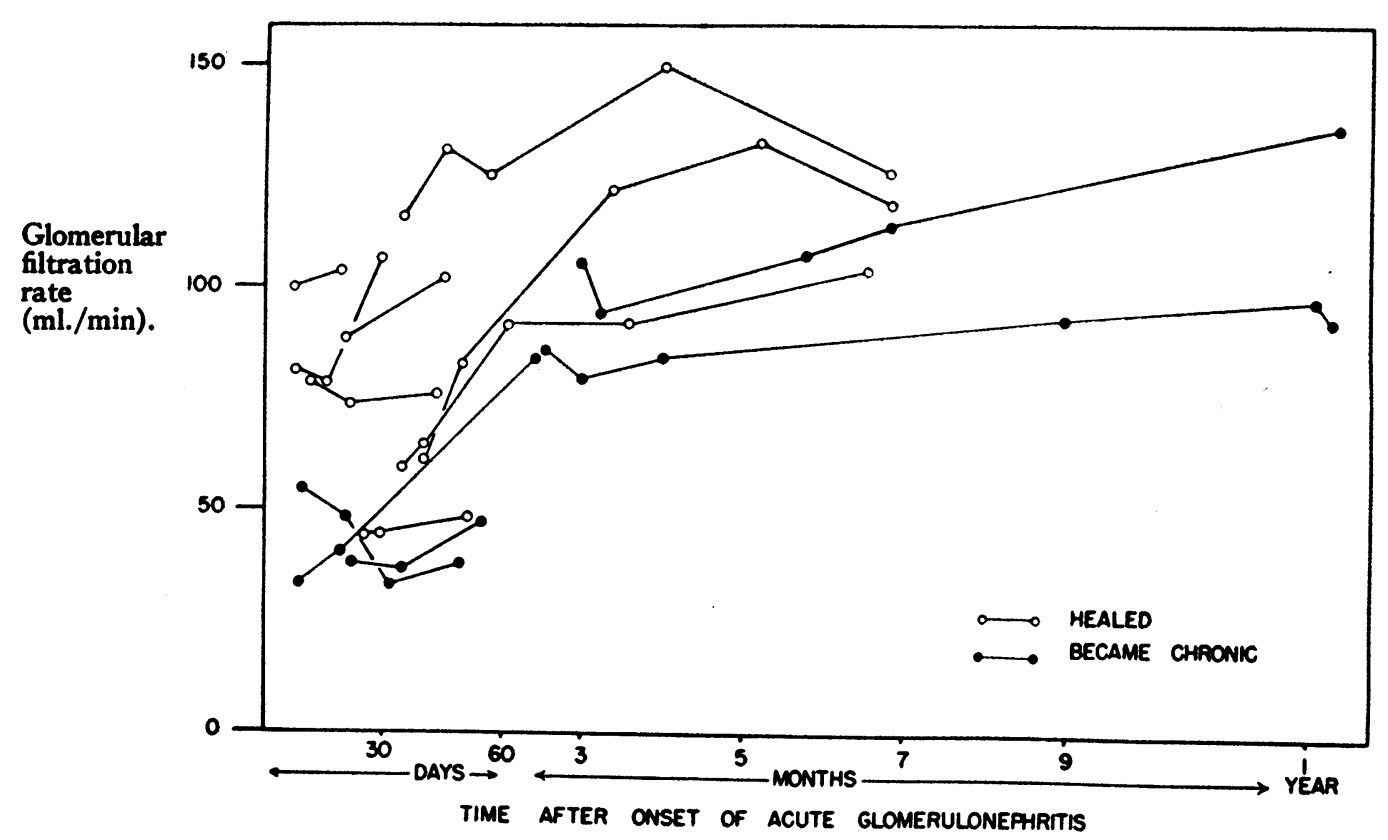

Fig. 1. Glomerular Filtration Rate in Relation to Time after Onset of Acute Glomerulonephritis

$59,81,87$ and $100 \mathrm{ml} . /$ minute. Return of filtration rate to the normal range, however, was not incompatible with the development of chronic renal disease, as in patients 4 and 9 of the earlier study (1). Conversely, patient 6 of the early study and patient 5 of the present study healed completely in spite of rather slow improvement in their glomerular filtration rates. Changes in $\mathrm{Tm}$ values showed the same general trends.
Concerning the inter-relations of the several renal functions, the filtration fraction usually increased as the acute renal process improved. However, no correlation could be established between this function or the ratio of filtration rate to excretory or reabsorptive $\mathrm{Tm}$ and the eventual outcome.

The exacerbations in chronic glomerulonephritis suffered by patients 9 and 11 were complicated

TAen IV

Glomerular filtration rate in relation to onset and end of diuresis in acute glomerulonephritis

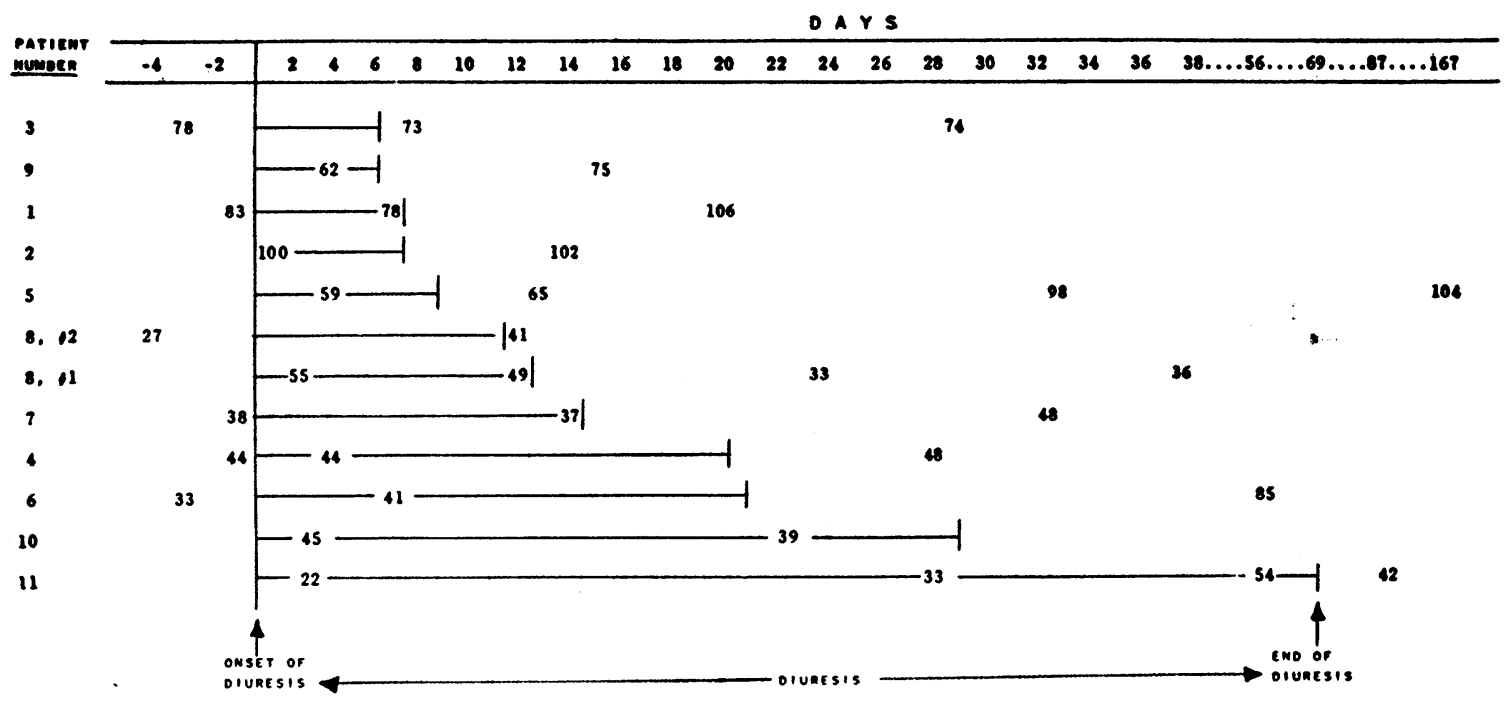


by congestive heart failure, as evidenced by dyspnea, orthopnea, increased venous pressure, prolonged circulation time and enlargement of the heart. Nevertheless, the functional changes were characteristic of acute glomerulonephritis with a low filtration fraction, rather than that of congestive heart failure with an elevated filtration fraction. Four other patients had slight transient cardiac enlargement by X-ray examination, but no other signs or symptoms suggestive of heart failure. All patients had hypertension at the time of the first measurement of renal function. In five the diastolic blood pressure was $100 \mathrm{~mm}$. $\mathrm{Hg}$ or more. In spite of the consistent hypertension, the filtration fraction was greater than the mean normal in only two instances. The blood pressure often returned to normal well before the renal function reached its maximum observed value.

(B) Relation of discrete renal functions to diuresis in the recovery phase of acute glomerulonephritis

The relation of glomerular filtration rate to diuresis in acute episodes of glomerulonephritis is indicated in Table IV. Daily excretion of electrolytes was followed in four of the patients (pa-

TABLE V

The relation of urea clearance to glomerular filtration rate and diuresis in acute glomerulonephritis

\begin{tabular}{|c|c|c|c|c|c|c|c|}
\hline \multirow[t]{2}{*}{ PATIENT } & \multirow[t]{2}{*}{$\begin{array}{l}\text { RELATION YO } \\
\text { OIURESIS } \\
\end{array}$} & \multirow{2}{*}{$\begin{array}{l}\text { URINE } \\
\text { FLOW } \\
\text { ml./min) }\end{array}$} & $\begin{array}{l}\text { GLOMERULAR } \\
\text { FILTRATION } \\
\text { RATE (GFR) }\end{array}$ & INULIN & UREA & \multirow[t]{2}{*}{ UC/GFR } & $\begin{array}{l}\text { PLASMA } \\
\text { UREA } \\
\end{array}$ \\
\hline & & & $\left(m l . / m i n_{0}\right)$ & & (ml./min.) & & $(\mathrm{mg} \cdot / 100 \mathrm{ml})$ \\
\hline 1 & $\begin{array}{l}\text { I day before } \\
\text { last day during }\end{array}$ & $\begin{array}{l}1.87 \\
1.46\end{array}$ & $\begin{array}{l}82.6 \\
78.0\end{array}$ & $\begin{array}{l}44.1 \\
53.5\end{array}$ & $\begin{array}{l}35.9 \\
66.7\end{array}$ & $\begin{array}{l}0.44 \\
0.86\end{array}$ & $\begin{array}{l}65.0 \\
23.0\end{array}$ \\
\hline 2 & $\begin{array}{l}\text { lst day during } \\
7 \text { days after }\end{array}$ & $\begin{array}{l}6.09 \\
4.07\end{array}$ & $\begin{array}{l}100 \\
102\end{array}$ & $\begin{array}{l}16.4 \\
24.5\end{array}$ & $\begin{array}{l}28.0 \\
80.0\end{array}$ & $\begin{array}{l}0.28 \\
0.79\end{array}$ & $\begin{array}{l}94.7 \\
20.7\end{array}$ \\
\hline 3 & $\begin{array}{l}3 \text { days before } \\
2 \text { days after } \\
23 \text { days after }\end{array}$ & $\begin{array}{l}2.69 \\
1.72 \\
2.62\end{array}$ & $\begin{array}{l}78.0 \\
73.4 \\
73.7\end{array}$ & $\begin{array}{l}29.0 \\
42.6 \\
28.1\end{array}$ & $\begin{array}{l}42.2 \\
39.4 \\
43.3\end{array}$ & $\begin{array}{l}0.54 \\
0.54 \\
0.59\end{array}$ & $\begin{array}{l}42.2 \\
39.4 \\
43.3\end{array}$ \\
\hline 4 & $\begin{array}{l}3 \text { days before } \\
2 \text { days after }\end{array}$ & $\begin{array}{l}1.30 \\
1.75\end{array}$ & $\begin{array}{l}43.5 \\
43.6\end{array}$ & $\begin{array}{l}33.4 \\
25.0\end{array}$ & $\begin{array}{l}25.7 \\
36.3\end{array}$ & $\begin{array}{l}0.59 \\
0.83\end{array}$ & $\begin{array}{l}48.0 \\
36.3\end{array}$ \\
\hline 6 & $\begin{array}{l}7 \text { th day during } \\
5 \text { weeks after }\end{array}$ & $\begin{array}{l}2.27 \\
1.92\end{array}$ & $\begin{array}{l}41.4 \\
84.8\end{array}$ & $\begin{array}{l}18.2 \\
44.2\end{array}$ & $\begin{array}{l}22.0 \\
71.8\end{array}$ & $\begin{array}{l}0.53 \\
0.85\end{array}$ & $\begin{array}{l}61.5 \\
26.2\end{array}$ \\
\hline 7 & $\begin{array}{l}1 \text { day before } \\
\text { last day during } \\
18 \text { days fter }\end{array}$ & $\begin{array}{l}2.29 \\
1.24 \\
2.21\end{array}$ & $\begin{array}{l}38.5 \\
37.0 \\
47.7\end{array}$ & $\begin{array}{l}16.8 \\
29.8 \\
21.6\end{array}$ & $\begin{array}{l}26.4 \\
19.5 \\
28.6\end{array}$ & $\begin{array}{l}0.69 \\
0.53 \\
0.60\end{array}$ & $\begin{array}{l}33.7 \\
47.4 \\
56.3\end{array}$ \\
\hline 8, 1 & $\begin{array}{l}\text { 2nd day during } \\
\text { last day during } \\
11 \text { days after } \\
26 \text { days after }\end{array}$ & $\begin{array}{l}1.93 \\
0.82 \\
2.62 \\
2.96\end{array}$ & $\begin{array}{l}54.9 \\
48.7 \\
33.3 \\
35.8\end{array}$ & $\begin{array}{l}28.4 \\
55.5 \\
12.7 \\
12.1\end{array}$ & $\begin{array}{l}35.6 \\
24.1 \\
26.6 \\
22.9\end{array}$ & $\begin{array}{l}0.65 \\
0.49 \\
0.80 \\
0.64\end{array}$ & $\begin{array}{l}46.6 \\
49.8 \\
57.2 \\
53.4\end{array}$ \\
\hline 9 & $\begin{array}{l}\text { 4th day during } \\
9 \text { days after }\end{array}$ & $\begin{array}{l}0.62 \\
1.02\end{array}$ & $\begin{array}{l}61.7 \\
74.6\end{array}$ & $\begin{array}{l}99.5 \\
73.3\end{array}$ & $\begin{array}{l}16.3 \\
31.2\end{array}$ & $\begin{array}{l}0.27 \\
0.42\end{array}$ & $\begin{array}{l}37.8 \\
28.7\end{array}$ \\
\hline 10 & $\begin{array}{l}\text { 3rd day during } \\
\text { 22nd day during }\end{array}$ & $\begin{array}{l}1.57 \\
1.26\end{array}$ & $\begin{array}{l}45.0 \\
38.6\end{array}$ & $\begin{array}{l}28.7 \\
30.7\end{array}$ & $\begin{array}{l}25.6 \\
26.1\end{array}$ & $\begin{array}{l}0.57 \\
0.68\end{array}$ & $\begin{array}{l}40.6 \\
33.6\end{array}$ \\
\hline 11 & $\begin{array}{l}\text { 3rd day during } \\
28 \text { th day during } \\
55 t h \text { day during } \\
22 \text { day after } \\
\text { \$1 at day after }\end{array}$ & $\begin{array}{l}0.96 \\
0.91 \\
3.18 \\
1.57 \\
1.57\end{array}$ & $\begin{array}{l}21.9 \\
32.9 \\
54.4 \\
41.7 \\
55.5\end{array}$ & $\begin{array}{l}22.8 \\
36.1 \\
17.1 \\
26.6 \\
36.4\end{array}$ & $\begin{array}{l}9.4 \\
15.8 \\
32.0 \\
27.5 \\
28.5\end{array}$ & $\begin{array}{l}0.43 \\
0.48 \\
0.59 \\
0.66 \\
0.51\end{array}$ & $\begin{array}{l}110 \\
59.6 \\
27.5 \\
26.7 \\
33.2\end{array}$ \\
\hline
\end{tabular}

Each datum represents the average of three consecutive periods. 
tients $1,2,4$ and 6 ). In the remaining patients the weight curve and clinical evidences of edema were utilized to assess diuresis. Filtration rates were measured before the beginning of diuresis in six instances. In the remaining six instances, filtration rate was first observed on the first to fourth day of diuresis (within a few hours of the onset of diuresis in patient 2). The data recorded in Table IV indicate that diuresis following acute glomerulonephritis is not accompanied by a consistent change in filtration rate.

Urea clearance was measured concomitantly with glomerular filtration rate in most of the studies (Table V). The relation of urea clearance to filtration rate and urine flow was not consistent when the group of patients with acute nephritis was considered as a whole. Considerable increases in urea clearance, however, occurred in five patients whose course was characterized by rapid loss of edema in the early phase of diuresis (patients 1, 2, 4, 6 and 9). In three of these the urea clearance increased with no change in glomerular filtration rate, and in each a definite rise in the ratio of urea/inulin ratio occurred. Nor were the increases in urea clearance attributable to concomitant changes in urine flow, which showed only minor variations among the observations obtained for a given patient.

In general, the plasma urea concentration reflected change in urea clearance, and in turn, the filtration rate. Abnormal plasma urea levels, however, did occur in several instances where the filtration rate was not greatly reduced (patients 1-3), while an increasing filtration rate was not incompatible with an increasing plasma urea (patient 7).

In a number of the observations the urea clearance was measured both before and during the infusion of glucose or PAH necessary for the Tm measurements. Urine flow increased in 25 of 27 such observations among 10 patients. The urea clearance increased more than 20 per cent in 11 instances, while the urea/inulin clearance ratio increased in 20 of the 27 observations. In general, the greatest increases were noted among those patients whose urine flows were low during the control periods and who showed substantial diuresis during the osmotic loads. These data indicate that the urea clearance may be influenced by osmotic diuresis in patients with acute glomerulonephritis.
The response of these patients to osmotic load was not unlike that observed among patients without renal disease (18).

\section{(C) Effects of acute glomerulonephritis on elec- trolyte metabolism}

Observations on the plasma or serum levels and the excretion rates of sodium, potassium, chloride, and inorganic phosphate are recorded in Table VI. Data on the excretion of ammonia and urinary $\mathrm{pH}$, and for reference purposes, concurrent filtration rates and urine flows, are included. The fraction of electrolyte filtered at the glomeruli that appeared in the urine also was calculated.

(1) Sodium: Serum sodium levels were usually in the normal range, although values between 132 and 135 meq./L were observed on occasion in six of the 12 acute episodes of glomerulonephritis. No correlation between the serum sodium level and the presence or absence of edema was noted. Sodium excretion, measured during the determination of filtration rate, was generally greater during the phase of diuresis than at other times. However, the necessity of giving intravenous infusions for clearance purposes probably distorted sodium excretion and urine flow to some extent, limiting the value of such observations. Variations in body weight or daily sodium excretion more accurately reflected sodium balance. But in any case, significant increase in sodium excretion could occur in the absence of change in filtration rate (patients 1 and 4).

(2) Chlorides: Plasma chloride levels typically were above normal in the patients with acute glomerulonephritis. The mean initial level for the 12 nephritic episodes was $114, \sigma=5.0$ meq./L, ranging up to 118 meq./L, as compared to 108 , $\sigma=3.3 \mathrm{meq} . / \mathrm{L}$ for 21 normal subjects observed under comparable conditions (i.e., during concomitant measurement of filtration rate and renal plasma flow). All but one of the nephritic patients had plasma chloride levels exceeding 110 meq./L at some time, while only five of the 21 normal subjects had levels greater than this value and none exceeded 114 meq./L. With one exception, the plasma chloride level did not return toward normal within the period of observation as the patients improved from their acute nephritis. Chloride excretion was usually approximately the same as sodium. 


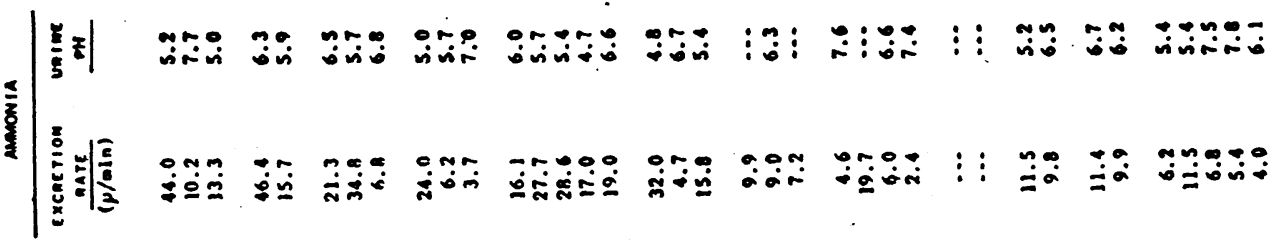

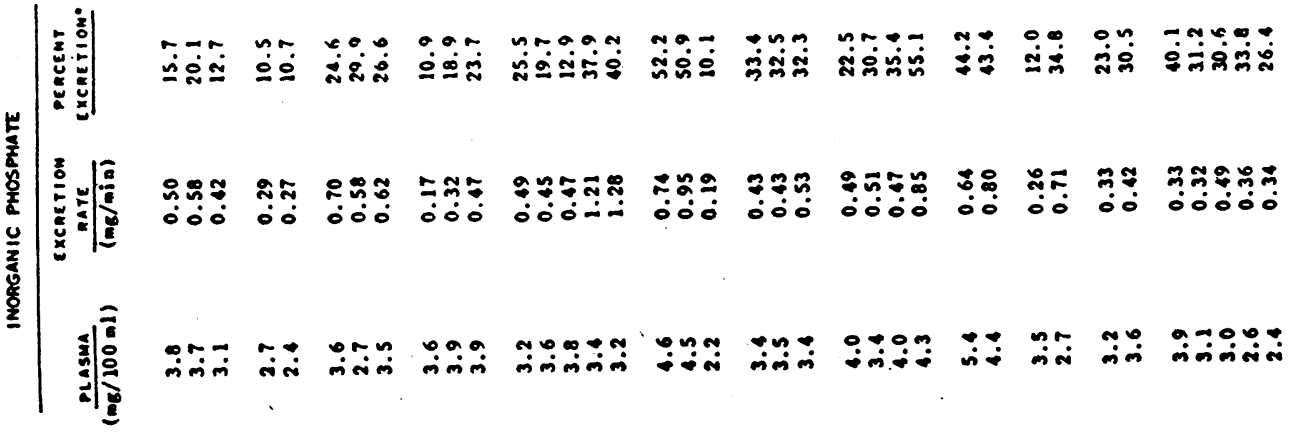

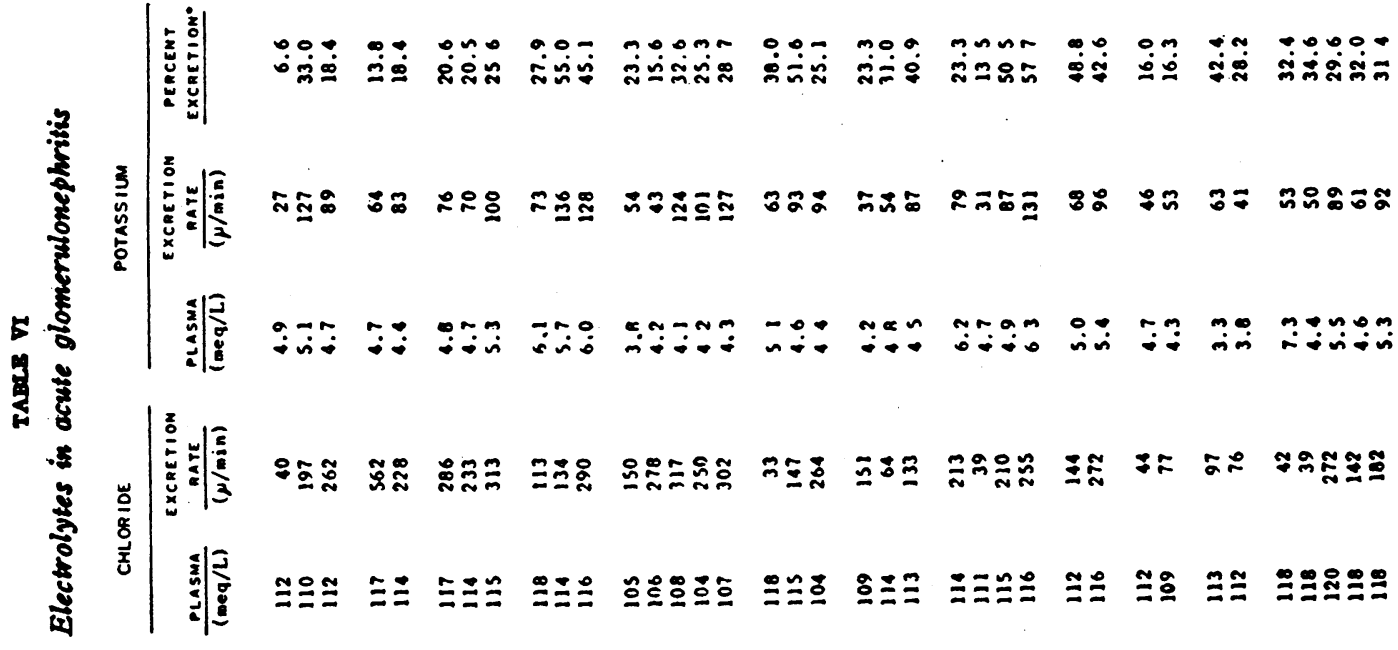

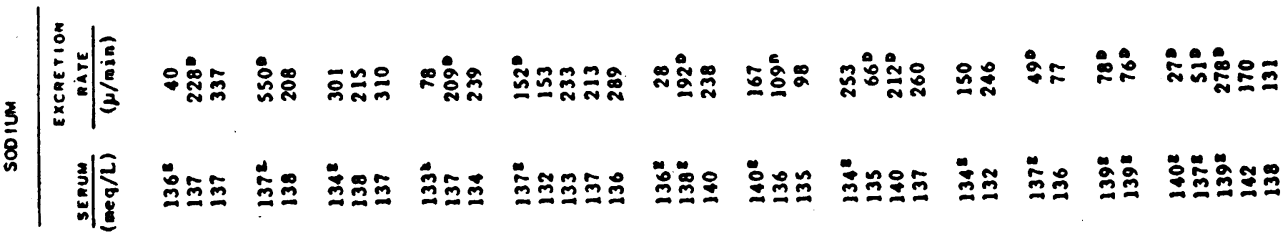

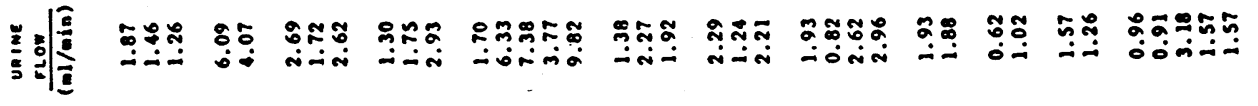

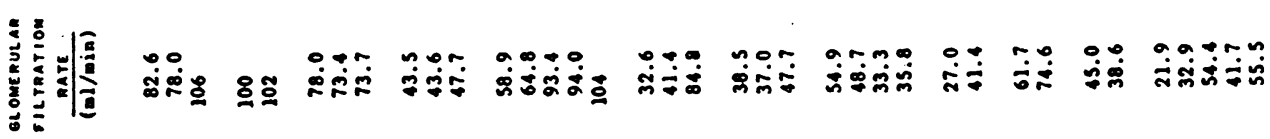

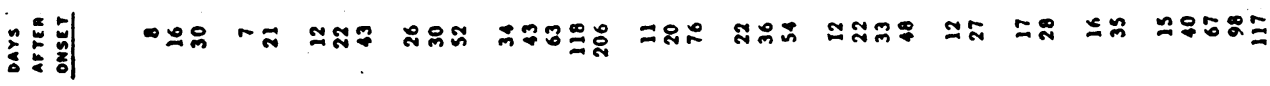
후일 
(3) Potassium: The average initial plasma potassium level for the 12 acute episodes of nephritis was $5.0 \mathrm{meq} . / \mathrm{L}, \sigma=1.08$, with a range of 3.3 to $7.3 \mathrm{meq} . / \mathrm{L}$. In contrast, the mean plasma potassium level, obtained under comparable circumstances (i.e., during measurement of glomerular filtration rate and renal plasma flow) in 21 subjects without renal disease was 4.2 meq. $/ \mathrm{L}, \sigma=0.29$, with a range of 3.4 to 4.8 . Only two of the normals had plasma potassium levels greater than 4.5 meq./L, while 10 of the 12 acute nephritics had values greater than this at one time or another. Patient 6 who had relatively low plasma potassium levels was the only one of the group who suffered vomiting prior to the observations. Abnormally high plasma potassium levels occurred in two patients whose filtration rates were not greatly reduced (patients 1 and 3 ), while conversely several of the patients with the lowest filtration rates had relatively normal plasma potassium levels. As was the case with plasma chloride, potassium plasma concentration was frequently above normal some days after recovery from acute nephritis.

The absolute values for potassium excretion in the urine showed a distinct tendency to rise as diuresis and recovery from the acute renal disease took place. Normally, less than 20 per cent of the potassium filtered at the glomeruli appears in the urine (18). However, the fraction of filtered potassium which was excreted exceeded this value at some time in 10 of the 12 acute episodes of glomerulonephritis. This phenomenon was most apparent among the patients with the greatest reductions in filtration rate but the relationship was not precise. Variations in excretion occurred independently of the plasma potassium level.

(4) Inorganic phosphate: The plasma level and urinary excretion of inorganic phosphate appear to be affected in acute glomerulonephritis to a lesser and more variable degree than potassium. The average initial plasma inorganic phosphate level for the 12 episodes was $3.7 \mathrm{mg} . / 100 \mathrm{ml}$., $\sigma=0.56 \mathrm{mg} . / 100 \mathrm{ml}$., as compared to $3.0 \mathrm{mg} . / 100$ ml., $\sigma=0.47 \mathrm{mg} . / 100 \mathrm{ml}$. for 13 normal subjects under similar circumstances (i.e., during measurement of filtration rate). Only three of the nephritics had at any time a plasma inorganic phosphate level greater than the mean normal plus two standard deviations. Plasma levels of potas- sium and inorganic phosphate did not necessarily parallel one another. Unlike potassium, urinary inorganic phosphate excretion increased with improvement in the renal lesion only occasionally. The fraction of filtered inorganic phosphate which was excreted by 13 normal subjects was quite variable, with a range from 2.3 to $26.5 \mathrm{mg} . / 100 \mathrm{ml}$., a mean of $13.0 \mathrm{mg} . / 100 \mathrm{ml}$., $\sigma=7.5$. Nevertheless, the mean normal value plus two standard deviations was exceeded in nine of the 12 episodes of acute nephritis.

(5) Ammonia excretion: The mean ammonia excretion rate in nine normal subjects, measured during the estimation of glomerular filtration rate and renal plasma flow, was 13 microeq./minute. One subject's rate was 2.7 microeq./minute, while the rates in the remainder varied between 11.6 and $18.2 \mathrm{microeq} . / \mathrm{minute}$. Somewhat increased rates of ammonia excretion, varying between 21.3 and 46.4 microeq./minute, were observed in five patients (patients 1-4 and 6) during the early phases of their acute glomerulonephritis (within two weeks of onset). The excretion rates in these patients subsequently fell to between 3.7 and 15.8 microeq./minute. These changes in ammonia excretion could not be correlated precisely with the urinary $\mathrm{pH}$. Several of the remaining patients occasionally exhibited ammonia excretion greater than the normal group, but generally the rates were in the neighborhood of $10 \mathrm{microeq} . /$ minute or less.

\section{DISCUSSION}

The pattern of renal dysfunction in acute glomerulonephritis appears to be quite characteristic. Typically the glomerular filtration rate is reduced. Function of the proximal convoluted tubules as measured by the maximum excretory capacity for diodrast $\left(T m_{D}\right)$ or $p$-aminohippurate $\left(T m_{\mathbf{P A B}}\right)$ may also be reduced, but low filtration rate to $\mathrm{Tm}$ ratios reflect the greater impairment of glomerular activity. Reabsorptive capacity for glucose may also be impaired but this function and the excretory capacity of the tubules may be affected to different degrees in the same patient.

That the reduced filtration fraction observed in acute glomerulonephritis represents a greater barrier to glomerular filtration than to the passage of blood through the glomerular apparatus has been suggested in an earlier study (1). It is recognized 
that, in fatal instances the glomerular tuft changes may be such as to obstruct the flow of blood. This mechanism may account for the usual autopsy description of "bloodless" glomeruli in such patients. ${ }^{4}$ However, in milder forms of the disease, high $\mathrm{RPF} / \mathrm{Tm}$ ratios indicate relative renal hyperemia, and at times, actual renal hyperemia (1).

The characteristic renal functional disturbances of acute glomerulonephritis can persist in spite of circumstances that are ordinarily associated with quite different patterns of dysfunction. Thus, congestive heart failure (19-21) and hypertension (22) are characterized by considerable reduction in the renal plasma flow and by increased filtration fraction. However, a decreased filtration fraction was observed in one patient whose acute glomerulonephritis was complicated by congestive heart failure, while the other patient with the same complication had a normal filtration fraction. Similarly, low filtration fractions occurred in many of the patients with acute nephritis in spite of significant hypertension.

The majority of instances of acute glomerulonephritis heal completely, especially in the younger age group. Unfortunately, accurate prognosis in the early phases of the disease is practically impossible. Renal function studies during the early stages of acute nephritis are of little or no assistance in determining the prognosis. Although the patients in this study who had the greatest impairment of function did not recover, many observers have commented that even the most severe uremia is not incompatible with complete recovery (7). Conversely, the acute disease may be so mild as to almost escape attention and yet fail to heal (7).

The functional changes during the exacerbation of chronic glomerulonephritis are similar to those of the initial acute episode. However, because renal function is usually already reduced to some degree in patients with the chronic disease, recovery of function following the exacerbation is not ordinarily as complete as it is following the initial acute attack.

Edema is one of the most common manifesta-

4 The amount of blood in the glomerular capillaries in an autopsy specimen does not necessarily reflect the amount of blood present during life. Very few erythrocytes are seen in the glomerular capillaries of animals sacrificed with entirely normal kidneys. tions of acute glomerulonephritis. Many observers believe that generalized capillary damage accounts for the edema in the majority of instances. This belief is based chiefly on the common localization of edema about the face and especially about the eyes (23), on the occurrence of edema and hypertension prior to or even without urinary abnormalities (24) and on older observations that edema fluid of acute glomerulonephritis contained relatively high amounts of protein (25). However, obvious accumulation of edema in the loose tissue of the face is not surprising in patients with fluid retention who are confined to bed and who do not have local or general elevation of venous pressure. Nor does the development of edema and hypertension prior to the appearance of urinary abnormalities preclude the possibility of early renal functional involvement. And the most recent observation on the edema fluids of acute nephritis reports the low protein content characteristic of transudates rather than of inflammatory reactions (26).

Congestive heart failure (27) was a contributing factor to the edema of only two of the 12 patients with acute glomerulonephritis in this study while none exhibited the nephrotic syndrome. A renal mechanism for fluid and salt retention in acute nephritis, therefore, should receive serious consideration. The observed reduction of filtration rate may well play some role in the pathogenesis of the edema of acute glomerulonephritis. This is especially likely in those patients whose filtration rates were reduced suddenly and severely. However, at least one patient with massive edema had a filtration rate within the normal range. Further, the urea clearance in acute glomerulonephritis is not infrequently reduced out of proportion to the filtration rate and the degree of oliguria. Reabsorption of urea by the renal tubules appears to represent passive diffusion (28). A possible explanation of the low urea/inulin clearance ratio in these instances of acute glomerulonephritis could be damage to the renal epithelium. Such damage perhaps could permit increased back diffusion of salt as well as of urea. Certainly, the present data indicate, at least, that the diuresis during recovery from an episode of acute glomerulonephritis can take place without a concomitant increase in glomerular filtration rate. The increases in urea clearance with diure- 
sis were not entirely dependent on the increase in urine flow, and thus may have been the result of reconstitution of the renal epithelium with return of function toward normal.

Abnormalities in the plasma concentration and excretion of sodium, potassium, chloride and inorganic phosphate, although common in acute glomerulonephritis were not well correlated with observed changes in renal functions. An increased fraction of filtered potassium excreted in the urine was one of the most consistent electrolyte abnormalities in acute nephritis. This phenomenon has previously been noted in patients with advanced renal failure (29) and probably represents a fortunate shift in glomerulo-tubular balance that permits maintenance of the plasma potassium level as closely as possible to the normal range in the face of decreased filtered loads of the ion. Whether decreased tubular absorption of potassium or increased tubular excretion, both of which theoretically can occur in chronic renal disease (29, 30 ), is responsible is not certain.

Ammonia excretion appeared to be increased somewhat during the early phases of acute glomerulonephritis. Although rates of ammonia excretion did not correlate precisely with urinary $\mathrm{pH}$, the increased ammonia in the urine perhaps represented a response to the acidosis that may have been present. Subsequently, ammonia excretion fell below the rates usually observed in normals, perhaps because of damage to the distal renal tubule cells.

\section{SUMMARY AND CONCLUSIONS}

1. The typical renal functional disturbances in an acute episode of glomerulonephritis issues from the characteristic glomerular lesion which leads to an excessive reduction in filtration rate and filtration fraction. Excretory and reabsorptive functions, as measured by $\mathrm{Tm}_{\mathrm{PAB}}$ and $\mathrm{Tm}$ glucose, respectively, are less extensively reduced.

2. The changes in renal functions are similar in the exacerbation in chronic glomerulonephritis.

3. The typical changes are noted in spite of hypertension or the development of congestive heart failure, conditions otherwise characterized by an increased filtration fraction.

4. The degree of abnormality and altered interrelations of renal functions are of little assistance in arriving at a prognosis. Considerable improve- ment in all functions usually follows an acute episode, although the rate of recovery is highly variable. Function also improves following an exacerbation but does not return to normal because of pre-existing impairment effected by chronic disease.

5. Salt and water diuresis during the recovery phase of acute glomerulonephritis may take place without change in glomerular filtration rate. Urea clearance is sometimes reduced out of proportion to the filtration rate in acute glomerulonephritis, and during recovery may increase without change in filtration rate.

6. Serum sodium concentration is normal or slightly low while plasma chloride, potassium and inorganic phosphate levels are sometimes above normal. These changes are not related to the degree of abnormality observed in renal functions.

7. Sodium and chloride excretion more or less parallel one another. Potassium excretion is depressed during the early stages of acute glomerulonephritis and increases during the diuresis of the recovery phase. A greater fraction than normal of filtered potassium and inorganic phosphate appear in the urine in the majority of patients.

8. Ammonia excretion is greater than normal during the early phases of acute glomerulonephritis but subsequently falls below the usual normal range.

\section{REFERENCES}

1. Earle, D. P., Jr., Taggart, J. V., and Shannon J. A., Glomerulonephritis. A survey of the functional organization of the kidney in various stages of diffuse glomerulonephritis. J. Clin. Invest., 1944, 23, 119.

2. Corcoron, A. C., Taylor, R. D., and Page, I. H., Functional patterns in renal disease. Ann. Int. Med., 1948, 28, 560.

3. Brun, C., Hilden, T., and Raaschou, F., Physiology of the diseased kidney. Acta med. Scandinav. Suppl., 1949, 234, 71.

4. Bradley, S. E., Bradley, G. P., Tyson, C. J., Curry, J. J., and Blake, W. D., Renal function in renal disease. Am. J. Med., 1950, 9, 766.

5. Todd, E. W., Antihaemolysin titres in haemolytic streptococcal infections and their significance in rheumatic fever. Brit. J. Exper. Path., 1932, 13, 248.

6. Addis, T., Glomerular Nephritis; Diagnosis and Treatment. Macmillan Co., New York, 1948.

7. Loeb, R. F., Nephritis, in Textbook of Medicine, edited by Cecil, R. L. W. B. Saunders Co., Philadelphia, 7th edition, 1947, p. 1020. 
8. Seegal, D., Lyttle, J. D., Loeb, E. N., Jost, E. L., and Davis, G., On the exacerbation in chronic glomerulonephritis. J. Clin. Invest., 1940, 19, 569.

9. Longcope, W. T., Bo:dley, J., III, and Lukens, F. D. W., Infection by streptococci in relation to recovery and progress in nephritis, in Kidney in Health and Disease, edited by Berglund, H., and Medes, G. Lea \& Febiger, Philadelphia, 1935, p. 330.

10. Harrison, H. E., A modification of the diphenylamine method for the determination of inulin. Proc. Soc. Exper. Biol. \& Med., 1942, 49, 111.

11. Alving, A. S., Rubin, J., and Miller, B. F., A direct colorimetric method for the determination of inulin in blood and urine. J. Biol. Chem., 1939, 127, 609.

12. Bratton, A. C., and Marshall, E. K., Jr., A new coupling component for sulfanilamide determination. J. Biol. Chem., 1939, 128, 537.

13. Shannon, J. A., and Fisher, S., The renal tubular reabsorption of glucose in the normal dog. Am. J. Physiol., 1938, 122, 765.

14. Jeffery, W. H., Note on the Volhard-Harvey method for estimation of chlorides in urine. J. Lab. \& Clin. Med., 1927, 13, 687.

15. Fiske, C. H., and SubbaRow, Y., The colorimetric determination of phosphorus. J. Biol. Chem., 1925, 66, 375 .

16. Hawk, P. B., Oser, B. L., and Summerson, W. H., Practical Physiological Chemistry. The Blakiston Co., Philadelphia, 12th ed., 1947, p. 502.

17. Goldring, W., and Chasis, H., Hypertension and $\mathrm{Hy}-$ pertensive Disease. The Commonwealth Fund, New York, 1944, p. 56.

18. Earle, D. P., Farber, S. J., Alexander, J. D., and Pellegrino, E. D., Unpublished observations.

19. Seymour, W. B., Pritchard, W. H., Longley, L. P., and Hayman, J. M., Jr., Cardiac output, blood and interstitial fluid volumes, total circulating serum protein, and kidney function during cardiac fail- ure and after improvement. J. Clin. Invest., 1942, 21, 229.

20. Warren, J. V., and Stead, E. A., Jr., Fluid dynamics in congestive heart failure: interpretation of mechanisms producing edema, increased plasma volume and elevated venous pressure in certain patients with prolonged congestive failure. Arch. Int. Med., 1944, 73, 138.

21. Merrill, A. J., Edema and decreased renal blood flow in patients with chronic congestive heart failure: evidence of "forward failure" as the primary cause of edema. J. Clin. Invest., 1946, 25, 389.

22. Goldring, W., Chasis, H., Ranges, H. A., and Smith, H. W., Effective renal blood flow in subjects with essential hypertension. J. Clin. Invest., 1941, 20, 637.

23. Cited by Bradley, S. E., in Combined Staff Clinics, Acute diffuse glomerulonephritis. Am. J. Med., 1949, 7, 382.

24. Brod, J., Acute diffuse glomerulonephritis. Am. J. Med., 1949, 7, 317.

25. Beckmann, K., Edema. Deutsches Arch. f. klin. Med., 1921, 135, 39.

26. Warren, J. V., and Stead, E. A., Jr., The protein content of edema fluid in patients with acute glomerulonephritis. Am. J. M. Sc., 1944, 208, 618.

27. La Due, J. S., Role of congestive heart failure in production of edema of acute glomerulonephritis. Ann. Int. Med., 1944, 20, 405.

28. Austin, J. H., Stillman, E., and Van Slyke, D. D., Factors governing the excretion rate of urea. J. Biol. Chem., 1921, 46, 91.

29. Leaf, A., and Camara, A. A., Renal tubular secretion of potassium in man. J. Clin. Invest., 1949, 28, 1526.

30. Earle, D. P., Sherry, S., Eichna, L. W., and Conan, N. J., The low potassium syndrome due to defective renal tubular mechanisms for handling potassium. Am. J. Med., in press. 